\title{
Identification and characterization of Clonorchis sinensis cathepsin B proteases in the pathogenesis of clonorchiasis
}

Wenjun Chen ${ }^{1,2 \dagger}$, Dan Ning ${ }^{1,2,3 \dagger}$, Xiaoyun Wang ${ }^{1,2+}$, Tingjin Chen ${ }^{1,2 \dagger}$, Xiaoli Lv ${ }^{4}$, Jiufeng Sun ${ }^{3}$, De Wu ${ }^{3}$, Yan Huang ${ }^{1,2}$, Jin $X u^{1,2^{*}}$ and Xinbing $Y u^{1,2^{*}}$

\begin{abstract}
Background: Human clonorchiasis is a prevailing food-borne disease caused by Clonorchis sinensis infection. Functional characterizations of key molecules from C. sinensis could facilitate the intervention of C. sinensis associated diseases.
\end{abstract}

Methods: In this study, immunolocalization of C. sinensis cathepsin B proteases (CsCBs) in C. sinensis worms was investigated. Four CsCBs were expressed in Pichia pastoris yeast cells. Purified yCsCBs were measured for enzymatic and hydrolase activities in the presence of various host proteins. Cell proliferation, wound-healing and transwell assays were performed to show the effect of CsCBs on human cells.

Results: CsCBs were localized in the excretory vesicle, oral sucker and intestinal tract of C. sinensis. Recombinant yCsCBs from yeast showed active enzymatic activity at $\mathrm{pH} 5.0-5.5$ and at $37-42^{\circ} \mathrm{C}$. yCsCBs can degrade various host proteins including human serum albumin, human fibronectin, human hemoglobin and human IgG. CsCBs were detected in liver tissues of mice and cancer patients afflicted with clonorchiasis. Various bioassays collectively demonstrated that CsCBs could promote cell proliferation, migration and invasion of human cancer cells.

Conclusion: Our results demonstrated that CsCBs can degrade various human proteins and we proved that the secreted CsCBs are involved in the pathogenesis of clonorchiasis.

Keywords: Clonorchis sinensis, Clonorchiasis, Cathepsin B, Pathogenesis

\section{Background}

Clonorchiasis is a food-borne parasitic disease caused by infection with Clonorchis sinensis (C. sinensis). Mammals are often infected with $C$. sinensis by consuming raw or uncooked fish or shrimp containing infectious metacercaria. Adult worms reside in the bile ducts of hosts and secreted products from $C$. sinensis eventually lead to clonorchiasis resulting in: cholangectasis, cholecystitis, cholelithiasis, hepatic fibrosis, and even liver cancer and bile duct cancer [1-3]. It is estimated that about 35 million people are afflicted with clonorchiasis, with most cases in Asian countries such as Korea, China and

\footnotetext{
* Correspondence: xujinteam@163.com; yuhxteam@163.com

${ }^{\dagger}$ Equal contributors

${ }^{1}$ Department of Parasitology, Zhongshan School of Medicine, Sun Yat-sen University, Guangzhou, Guangdong 510080, People's Republic of China Full list of author information is available at the end of the article
}

Vietnam [4, 5]. Food security problems caused by liver flukes have attracted high attention of public health, increasing the urgency of finding new approaches to prevent the spread of clonorchiasis. Clonorchiasis is listed among food-borne parasitic diseases requiring urgent control in China.

With the recent progress of the $C$. sinensis genome and transcriptome [6,7], scientific researchers have expended much effort to elucidate the underlying mechanism of carcinogenic liver fluke associated hepatobiliary diseases $[8,9]$. Molecular characterizations of key pathogenic molecules could speed up the interventions of $C$. sinensis infection. Cysteine proteases of helminthes have been widely characterized for their biological functions, including digestion, encystation, excystation, immune evasion and tissue invasion $[10,11]$. Although cysteine proteases are abundant in C. sinensis transcriptome, 
limited information is available to illustrate the biological roles for $C$. sinensis in the host. Biological roles of $C$. sinensis cathepsin B proteases (CsCBs) have not been sufficiently investigated, although extensive studies demonstrate the importance of cathepsins in other organisms.

In our previous work [12], we performed preliminary functional characterizations of four $C$. sinensis cathepsin $\mathrm{B}$ cysteine proteases (CsCB1, CsCB2, CsCB3 and Cs CB4). Cs CBs were cloned into a prokaryotic expression vector (pET-28a) and expressed in the form of inclusion bodies in E. coli. Purified proteins from E. coli (eCsCBs) were identified as C. sinensis excretory/ secretory products and could trigger immune responses. However, we failed to perform further functional characterizations of these cysteine proteases due to loss of enzyme activity during the renaturation procedure. In this study, the eukaryotic expressing system in yeast was constructed using homologous recombination to express four yCsCBs (CsCB1, CsCB2, CsCB3 and CsCB4) in Pichia pastoris $\mathrm{X} 33$ yeast cells. Recombinant yCsCBs showed enzymatic activities and hydrolase activities in degrading various host proteins. $\mathrm{Cs} \mathrm{CB}$ was detected in the liver tissues of mice and cancer patients afflicted with clonorchiasis. Recombinant $\mathrm{Cs} C \mathrm{CB}$ could promote cell proliferation, migration and invasion of human cancer cells. Our results provide evidence to support the role of $\mathrm{Cs} C B s$ in the pathogenesis of clonorchiasis.

\section{Methods}

\section{Parasites, animals and patient samples}

C. sinensis worms (larva, juvenile and adult) were freshly isolated from artificially infected freshwater fishes or Sprague-Dawley rats as we previously described [13]. Ethical Approval: Male Sprague-Dawley rats were purchased from the animal center at Sun Yat-sen University and raised in accordance with the National Institutes of Health animal care and ethical guidelines. BALB/c mice (8-weeks-old) were intragastrically infected with metacercariae to establish the $C$. sinensis infected mice model. Mice in the control group were treated with phosphatebuffered saline (PBS). The mice were sacrificed at 8 weeks after the infection and liver tissues were isolated for immunohistochemistry. Clonorchiasis-induced liver cancer specimens acquired from People's Hospital of HengXian, Guangxi Zhuang Autonomous Region were pathologically diagnosed. Normal liver specimens were acquired from the first affiliated hospital of Sun Yat-Sen University. Ethical approval to use patients' samples in this study was obtained from local hospitals and animal procedures were approved by the animal care and use committee of Sun Yat-sen University (Permit Numbers: SCXK (Guangdong) 2009-0011).

\section{Immunolocalization of $\mathrm{Cs}$ CBs in adult worm, cercaria and} metacercaria

C. sinensis worms (larva, juvenile and adult) were used for the immunolocalization assay. Sectioned worms in paraffin wax were deparaffinized and incubated with previously prepared anti-CsCBs sera (1: 400 in dilution). Pre-immune rat serum was applied as a negative control. Subsequently, the sections were incubated with $\mathrm{Cy} 3$ conjugated goat anti-rat IgG secondary antibody (1: 400 in dilution, Alexa Fluor 594, Molecular Probe) at RT for $1 \mathrm{~h}$ and imaged using an Axio Imager Z1fluorescent microscope (ZEISS).

\section{Homologous recombination of $\mathrm{Cs} C \mathrm{CB}$ in yeast}

As we previously reported, the complete coding sequences of $\mathrm{Cs} C B s$ range from 1014 to $1044 \mathrm{bp}$, with an $\mathrm{N}$-terminal hydrophobic signal peptide ranging from 18 to 22 aa. To obtain recombinant $\mathrm{CsCBs}$ from the eukaryotic expressing system for functional characterizations, we performed a homologous recombination of CsCBs in the Pichia pastoris X33 yeast strain. The gene fragments of $\mathrm{Cs} C B s$ were amplified by $\mathrm{PCR}$ using primers (Table 1) according to CsCBs-ORF (signal peptide excluded) and restriction sites of shuttle vector $\mathrm{pPICZ} \alpha \mathrm{B}$. Recombinant colonies were screened by Zeocin followed by validation using PCR and sequencing. Confirmed plasmids were extracted from DH5 $\alpha$ and Pichia pastoris X33 was transformed with a Sac I linearized recombinant $\mathrm{pPICZ} \alpha \mathrm{B}$ vector. The transformants were selected for Zeocin resistance on YPD plates [14]. Genomic DNAs were extracted from positive transformants for PCR to further confirm homologous recombination.

\section{Expression and purification of $\mathrm{y} C s \mathrm{CBs}$}

Selected transformants were cultured in a BMGY medium for 16-18 h until $\mathrm{OD}_{600}$ of 2-6, cells were harvested by centrifugation and re-suspended in a BMMY medium at an $\mathrm{OD}_{600}$ of 1.0. The expression of $\mathrm{yCs} C \mathrm{CBs}$ was induced by the daily addition of $0.5 \%(v / v)$ methanol at 24, 48, 72 and $96 \mathrm{~h}$, respectively. The culture filtrate of recombinant X33 cells was concentrated using

Table 1 Primers used in this study

\begin{tabular}{lll}
\hline Gene & Primers & Gene length \\
\hline CsCB1 & F: 5'GCCGAATTCACGAGTATATTCCATCTTC3' & $960 \mathrm{bp}$ \\
& R: 5'CGCTCTAGAAGCAGTITGGATGACCAG3' & \\
CsCB2 & F: 5'GTCGAATTCACGAAAATCTGGGGAGCGT3' & $966 \mathrm{bp}$ \\
& R: 5'GCCTCTAGAACAAAATGCGGAATGGTGG3' & \\
CsCB3 & F: 5'CGACTGCAGGAACAGAATCGATTGGACT3' & $960 \mathrm{bp}$ \\
& R: 5'GGCTCTAGAATCTTAAGTGGGATGCTGG3' & \\
CsCB4 & F: 5'GTACTGCAGGAAAACCAAAGCACGAAGC3' & $987 \mathrm{bp}$ \\
& R: 5'GCGGTCTAGAGGCGAAAAGGATTCATGATT3' & \\
\hline
\end{tabular}


ammonium sulfate. Concentrated supernatant was used for SDS-PAGE and Western blotting experiments to examine the extracellular expression of $\mathrm{yCs} C B s$ in yeast. After that, recombinant protein was induced for $96 \mathrm{~h}$ and purified by His-bind resin chromatography (Novagen) followed by dialysis in PBS (pH7.2). Protein concentration was determined using the BCA method and stored at $-80{ }^{\circ} \mathrm{C}$ for enzymatic assays.

\section{SDS-PAGE and Western blotting}

Concentrated supernatant was subjected to $12 \%$ SDSPAGE stained with Coomassie brilliant blue. To further confirm extracellular expression of $\mathrm{Cs} C B s$ in X33 cells, concentrated supernatant was also subjected to Western Blotting. Protein samples were transferred onto a PVDF membrane (Millipore) followed by incubation with different antibodies: mouse anti-His antibody (1: 500 in dilution, Life Technologies), mouse anti-c-Myc monoclonal antibody (1: 500 in dilution, Life Technologies) and rat anti-CsCB1 antibody (1: 800 in dilution), which was produced in our previous study. HRP-conjugated goat antimouse IgG or goat anti-rat IgG (1: 2,000 in dilution) was further incubated with each membrane, followed by enhanced chemiluminescence (ECL).

\section{Enzyme activity assays}

The enzyme activity of yCsCBs was assayed fluorometrically according to the previous report [15]. Enzyme reactions were performed under different enzyme concentrations, $\mathrm{pH}$ values and temperatures, respectively. Typically, the measurements were performed at $37^{\circ} \mathrm{C}$ for $1 \mathrm{~h}$ in a $100 \mu \mathrm{l}$ mixture containing yCsCBs $(0-20 \mu \mathrm{M})$, fluorescent Z-PheArg-AMC/Z-Arg-Arg-AMC (20 $\mu \mathrm{M}$, Bachem), $10 \mathrm{mM}$ DTT, $0.05 \%$ Brij-35 (AMRESCO), EDTANa $2(1 \mathrm{mM})$, and $\mathrm{C}_{2} \mathrm{H}_{3} \mathrm{NaO}_{2} / \mathrm{Na}_{3} \mathrm{PO}_{4} /$ Tris- $\mathrm{HCl}(100 \mathrm{mM})$. The enzyme reaction was terminated by adding stop buffer $(70 \mathrm{mM}$ $\mathrm{C}_{2} \mathrm{H}_{4} \mathrm{O}_{2}, 30 \mathrm{mM} \mathrm{C} \mathrm{C}_{2} \mathrm{NaO}_{2}, 100 \mathrm{mM} \mathrm{C} \mathrm{C}_{2} \mathrm{H}_{2} \mathrm{ClO}_{2} \mathrm{Na}$, $\mathrm{pH}$ 4.3). Fluorescent intensity was measured by plate reader at $348 \mathrm{~nm}$.

\section{Degradation of host proteins}

We first investigated hydrolase activity of yCsCBs. Purified $\mathrm{Cs} \mathrm{CBs}$ from E. coli or from Pichia pastoris were loaded into a $12 \%$ SDS-PAGE containing $0.1 \%$ gelatin. The gel was washed with washing buffer $(2.5 \%$ Tritonx100, $50 \mathrm{mM}$ Tris-HCl, $5 \mathrm{mM} \mathrm{CaCl} 2, \mathrm{pH} 7.5)$, followed by incubation with $\mathrm{Na}_{3} \mathrm{PO}_{4}(100 \mathrm{mM}, \mathrm{pH} 7.5)$ at $37{ }^{\circ} \mathrm{C}$ for $24 \mathrm{~h}$. The hydrolase activity of $\mathrm{yCs} C B$ s was visualized by Coomassie brilliant blue staining.

Second, we tested whether yCsCBs could degrade host proteins, given that $\mathrm{Cs} C B s$ were proven components of secreted products of $C$. sinensis [12]. Purified yCsCBs were incubated with host proteins at $37{ }^{\circ} \mathrm{C}$ for $2 \mathrm{~h}$. Human serum albumin (MB-CHEM), human hemoglobin
(MB-CHEM), human IgG (MB-CHEM), human fibronectin (Sigma) and bovine serum albumin (MB-CHEM) were used as the substrates. The assays were performed in a $200 \mu \mathrm{l}$ mixture containing $\mathrm{Na}_{3} \mathrm{PO}_{4}(100 \mathrm{mM}, \mathrm{pH}$ 5.5), $\operatorname{EDTANa}_{2}(1 \mathrm{mM})$, DTT $(10 \mathrm{mM})$, yCsCBs $(20 \mu \mathrm{M})$ and various host proteins $(1 \mathrm{mg})$. The reactions were terminated by adding a reducing sample buffer and analyzed by SDS-PAGE.

\section{Inhibition effect on enzyme activity of yCsCBs}

To confirm the specificity of enzyme activity from the above-mentioned assays, we performed enzymatic inhibition experiments by using different enzyme inhibitors purchased from Sigma. Briefly, yCsCBs $(20 \mu \mathrm{M})$ were pre-incubated with or without protease inhibitors, including E-64 $(20 \mu \mathrm{M})$, iodoacetic acid $(10 \mu \mathrm{M})$, PMSF (2 mM), EDTA $(2 \mathrm{mM})$, AEBSF $(200 \mu \mathrm{M})$, TPCK $(200 \mu \mathrm{M})$ and CA-074 methyl ester $(1 \mu \mathrm{M})$. Z-Phe-ArgAMC $(20 \mu \mathrm{M})$ was added to the reactions after $30 \mathrm{~min}$ and incubated for another $1 \mathrm{~h}$. Each assay was performed in triplicate and enzyme activity was measured by plate reader at $348 \mathrm{~nm}$.

\section{Immunohistochemistry of $C_{s} C B$ in infected mouse and patient}

Next, we sought to investigate whether $\mathrm{Cs} C \mathrm{CBs}$ are involved in the pathogenesis of clonorchiasis using the $\mathrm{yCsCB} 4$ protein. First, we performed an immunohistochemistry using an anti-CsCB4 antibody to see the localization of $\mathrm{CsCB} 4$ in liver tissues of clonorchiasis afflicting mice and patients. Generally, tissue samples were fixed in $10 \%$ formalin and sectioned to $4 \mu \mathrm{m}$ in thickness. The sections were routinely treated with ethanol and slides were immersed in a $0.3 \%$ hydrogen peroxide solution for $20 \mathrm{~min}$ to block the endogenous peroxidase activity. The sections were then incubated overnight at $4{ }^{\circ} \mathrm{C}$ with rat anti-CsCB4 antibody (1: 100 in dilution). Sections were subsequently incubated with horseradish peroxidase (HRP) conjugated rat-specific secondary antibodies (1: 200 in dilution). Immunohistochemistry results were developed using diaminobenzidine $(\mathrm{DAB})$ and counterstained with hematoxylin. The images were taken under a light microscope (Leica DMI3000B) and subsequently analyzed using ImagePro Plus software (Media Cybernetics, Roper, USA). The brown staining was indicated as Integrated Optical Density (IOD), and IOD/Area was indicated as a relative expression level of $\mathrm{Cs} \mathrm{CB} 4$ in liver tissues.

\section{Cell proliferation analysis}

The cell proliferation level induced by $\mathrm{yCsCB} 4$ was measured in two human cancer cell lines, human hepatocellular carcinoma cell line (MHCC-97H, ATCC) and human cholangiocarcinoma cell line (RBE, ATCC). MHCC-97H 
and RBE cells were grown in DMEM (Hyclone, USA) and RPMI-1640 (Gibco, USA), respectively and supplemented with $10 \%$ fetal bovine serum (Gibco, USA) and $1 \%$ penicillin/streptomycin (Gibco, USA). Cells were incubated at $37{ }^{\circ} \mathrm{C}$ in a humidified chamber under $5 \%$ $\mathrm{CO}_{2}$. Cells at the logarithmic phase were plated into 96-well plates in triplicate and treated with yCsCB4 protein $(1 \mu \mathrm{g} / \mathrm{ml})$. Cell viability at $24 \mathrm{~h}$ was measured using Cell Counting Kit-8 (CCK-8) as previously described [16]. For cell cycle analysis using flow cytometry, cells were incubated with yCsCB4 $(1 \mu \mathrm{g} / \mathrm{ml})$ for $24 \mathrm{~h}$. Then the cells were trypsinized and fixed in $100 \%$ ethanol at $-20{ }^{\circ} \mathrm{C}$ overnight. Cell cycle distribution was determined by fluorescence activated cell

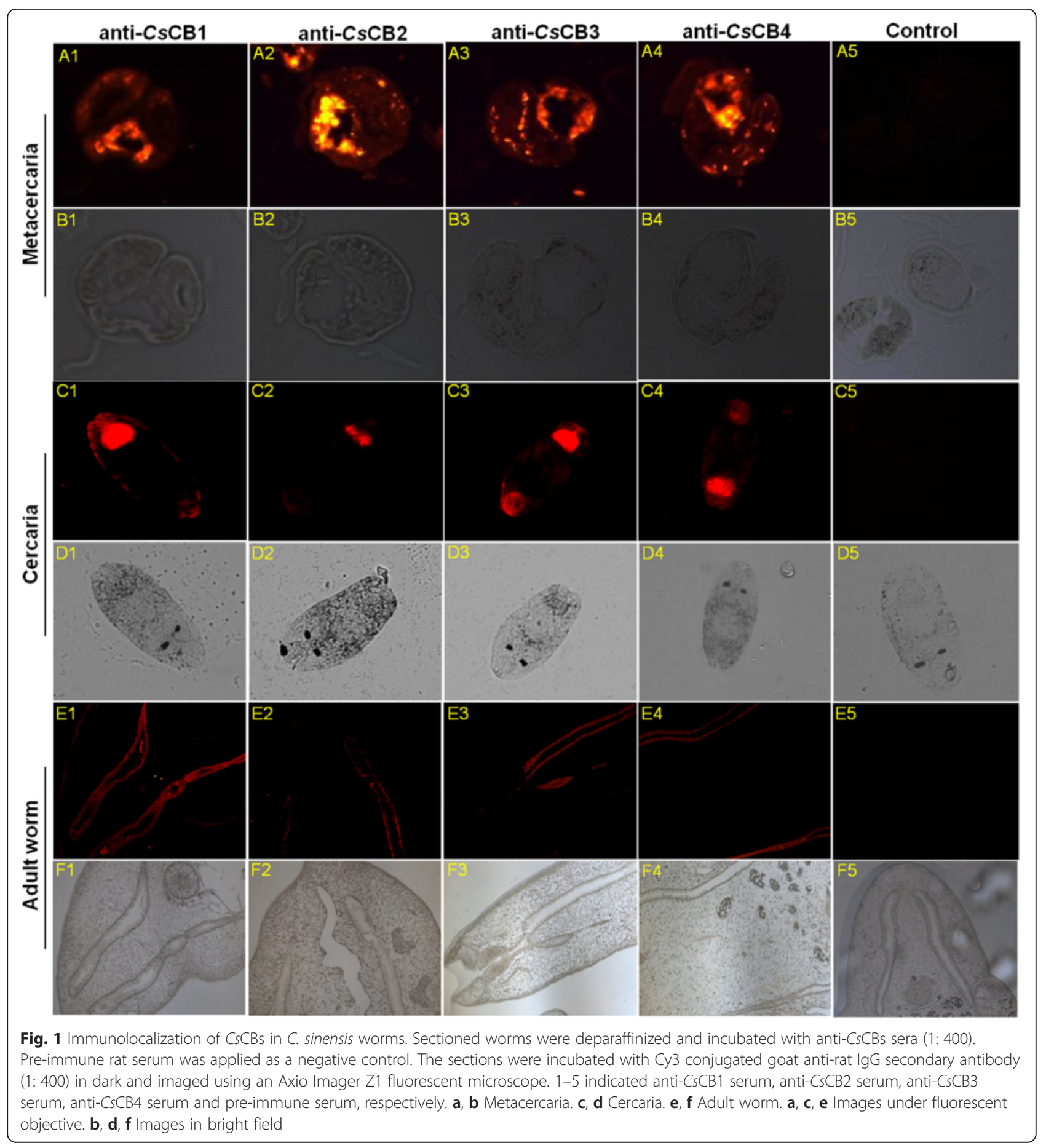


sorting (FACS). Data was analyzed using the FlowJo software.

\section{Cell migration and invasion assay}

To further confirm the role of yCsCB4 in human cancer cell growth, wound-healing assays were performed to evaluate the effect of $\mathrm{yCs} \mathrm{CB} 4$ on cell migration according to the previous method [17]. MHCC-97H and RBE cells seeded in 6-well plates were grown to $80 \%$ confluence and incubated with yCsCB4 $(1 \mu \mathrm{g} / \mathrm{ml})$ or PBS for $24 \mathrm{~h}$. Cells were wounded by scratching with pipette tips. Wounds at $24 \mathrm{~h}$ were observed and photographed under a light microscope (Leica DMI3000B).

To evaluate the effect of $\mathrm{yCs} C \mathrm{CB} 4$ on cell invasion, we performed transwell assays according to the method described elsewhere [18]. MHCC-97H and RBE cells were suspended in serum-free media and placed in $8 \mu \mathrm{m}$ pores. These inserts were placed in wells with serumcontaining media. Cells were incubated with yCsCB4 $(1 \mu \mathrm{g} / \mathrm{ml})$ or PBS for $24 \mathrm{~h}$. Invasion assays were performed using matrigel-coated membranes (BD, USA). The migration assay was similar to the invasion assay, except that the upper side of the membranes was not coated with the matrigel. Cells attached to the lower surface of the membranes at $24 \mathrm{~h}$ were counted under a light microscope.

\section{Statistical analysis}

Experimental data were obtained from three independent experiments with a similar pattern; data are expressed as means \pm standard deviation. All the data were analyzed by SPSS 13.0. Student's $t$-test and ANOVA were used to analyze the data. $P$ value $<0.05$ was considered statistically significant.

\section{Results}

Immunolocalization of $\mathrm{Cs} C B s$ in $C$. sinensis worms

In our previous work, we demonstrated that $\mathrm{Cs} C B s$ are components of $C$. sinensis secreted products by Western Blotting assay [12]. In this study, we first investigated the immunolocalization of four $\mathrm{Cs} C \mathrm{CBs}$ in $\mathrm{C}$. sinensis worms. As shown in Fig. 1, in metacercaria (Fig. 1, panel A1-A4) and cercaria (Fig. 1, panel C1-C4), four CsCBs could be detected in the excretory vesicle and oral sucker. In adult worm, four $C s C B s$ could be specifically observed in the intestinal tract (Fig. 1, panel E1-E4). No fluorescent signal could be detected in negative controls treated with pre-immune serum (Fig. 1, panel A5, C5 and E5).

\section{Homologous recombination of $\mathrm{Cs} C \mathrm{CB}$ in yeast}

As shown in Additional file 1: Figure S1, the ORFs of four $\mathrm{CsCBs}$ were successfully inserted into the shuttle vector $\mathrm{pPICZ} \alpha \mathrm{B}$. Selected transformants with $\mathrm{Cs} C B \mathrm{~s}$ were used for protein expression induced by methanol.
Cells were collected at different time points to monitor the expression level of $\mathrm{yCs} C B s$. As shown in Additional file 1: Figure S2, a band of interest around $45 \mathrm{kDa}$ appeared in the yeast culture medium at $24 \mathrm{~h}$ with an increased expressed level afterward, indicating the successful expression of yCsCBs in yeast (Additional file 1: Figure S2A-D). To further confirm whether the interesting band $(45 \mathrm{kDa})$ was $\mathrm{yCs} C \mathrm{CBs}$, a concentrated culture medium was used for Western blotting assays probed with different antibodies (Fig. 2 and Additional file 1: Figure S3). As expected, the interesting bands seen in SDS-PAGE could be recognized by His-tag (Fig. 2a). Expression of $\mathrm{yCs} C B s$ was also demonstrated by reactions with anti-c-Myc antibody and anti-CsCB1 antibody when $\mathrm{yCs} C \mathrm{CB} 1$ was used as the example (Fig. $2 \mathrm{~b}$ and $\mathrm{c}$ ). Eventually, four $\mathrm{yCs} C B s$ were purified by His-bind resin chromatography and analyzed by $12 \%$ SDS-PAGE, resulting in a highly pure $\mathrm{yCs} C B s$ (Additional file 1 : Figure S4, A-D).

\section{Enzyme activity of yCsCB}

We tested the enzyme activity of $\mathrm{yCs} C B s$ by using two fluorescent substrates (Z-Phe-Arg-AMC and ZArg-Arg-AMC). As shown in Fig. 3a, four yCsCBs were demonstrated to be active enzymes when the enzyme concentration ranged from 0 to $20 \mu \mathrm{M}$. Compared to Z-Arg-Arg-AMC, $\mathrm{yCs} C B$ s showed higher enzymatic
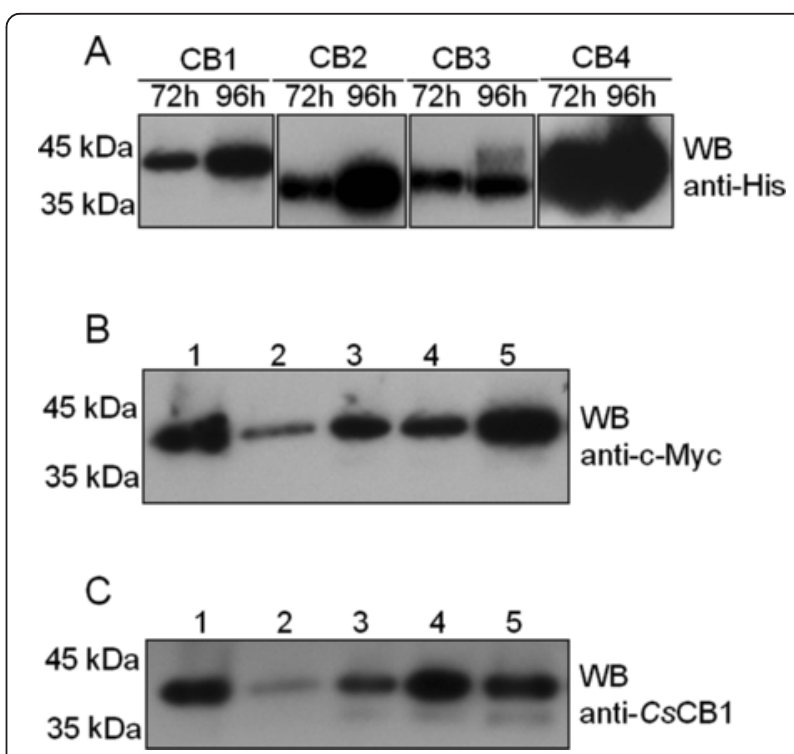

Fig. 2 Identification of extracellular expression of yCsCBs by Western Blotting. a Cell culture medium of yCsCBs (yCsCB1, yCsCB2, yCsCB3 and yCsCB4) was probed with mouse anti-His antibody (1: 500). b Cell culture medium of $y$ CsCB1 was probed with mouse anti-c-Myc antibody (1: 500). c Cell culture medium of $\mathrm{yCSCB} 1$ was probed with rat anti-CSCB1 antibody (1: 800). Lanes 1-5 indicated ammonium sulfate precipitate, 72-h culture medium, 96-h culture medium, 120-h culture medium and 144-h culture medium, respectively 


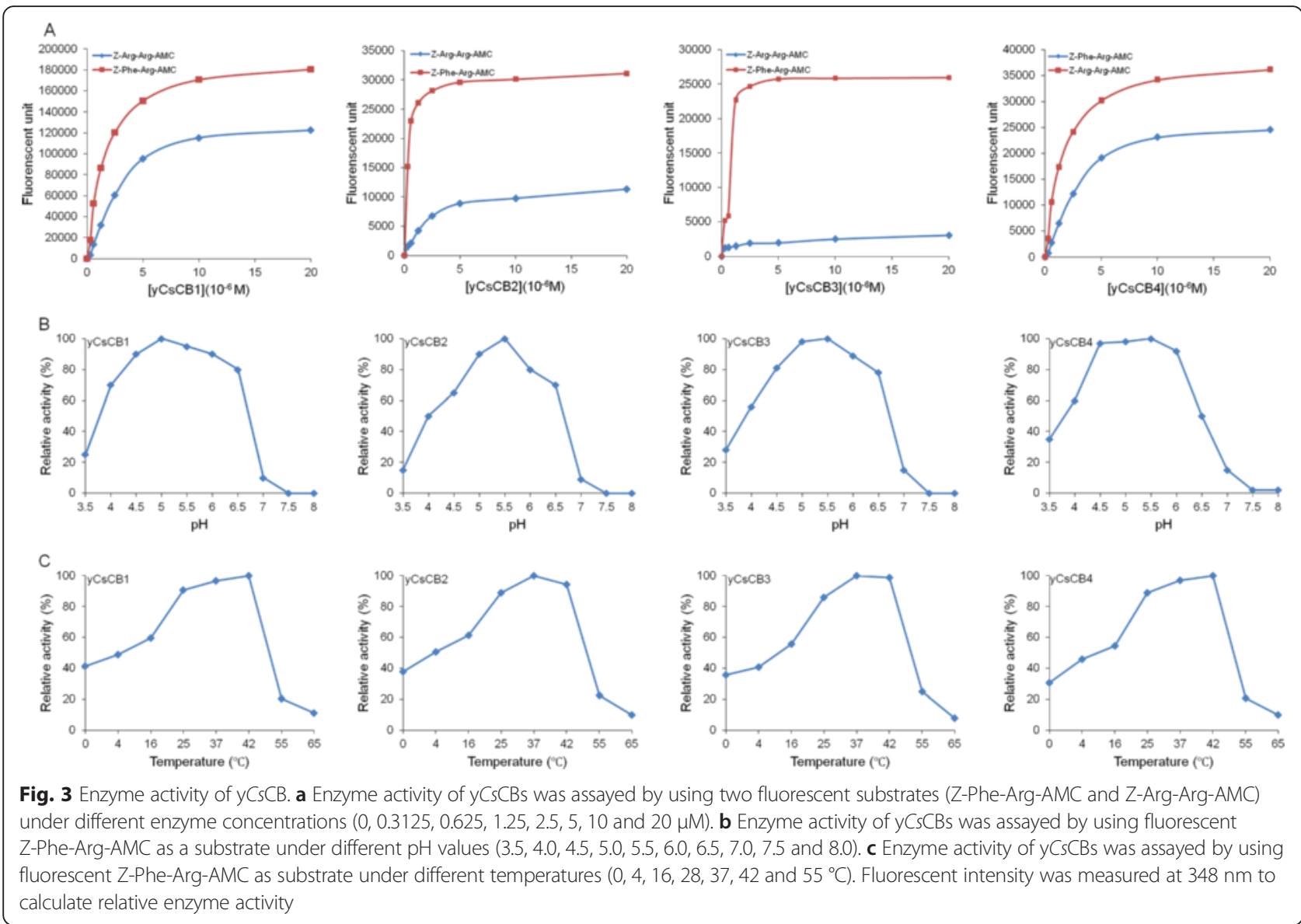

activity when Z-Phe-Arg-AMC was used as the substrate. In addition, optimal enzyme reaction $\mathrm{pH}$ values and temperatures were investigated. $\mathrm{yCs} C B s$ showed the highest enzymatic activity when enzyme assays were performed at $\mathrm{pH} 5.0-5.5$ (Fig. 3b) and at $37-42{ }^{\circ} \mathrm{C}$ (Fig. 3c). The results suggested that $\mathrm{yCs} C B s$ were stable enzymes under acidic conditions when temperatures ranged from 37 to $42{ }^{\circ} \mathrm{C}$.

\section{Host proteins degradation by y $\mathrm{Cs} \mathrm{CBs}$}

Since $\mathrm{Cs} C B s$ have been demonstrated to be the components of secreted products of $C$. sinensis, we tested hydrolase activity of $\mathrm{yCs} C B s$ within the context of host proteins under acidic conditions ( $\mathrm{pH}$ 5.5). In gelatin hydrolysis assay (Fig. 4a), yCsCBs could obviously hydrolyze gelatin, while eCsCBs could not. When bovine serum albumin was used as the substrate, four $\mathrm{yCs} C B$ s also showed a degradation effect with different activities (Fig. 4b). We then employed different host proteins as the substrate; four $\mathrm{yCs} C \mathrm{CBs}$ could degrade host proteins including human serum albumin (Fig. 4c), human fibronectin (Fig. 4d), human hemoglobin (Fig. 4e) and human IgG (Fig. 4f).

\section{Inhibition effect on enzyme activity of yCsCBs}

As we showed above, four yCsCBs were demonstrated as active enzymes. We carried out inhibiting assays using different enzyme inhibitors to confirm that observed enzyme activity was specific to cathepsin B proteases (Fig. 5). Compared to controls without enzyme inhibitors, enzymatic activities of $\mathrm{yCs} C B s$ could be completely inhibited by cathepsin $\mathrm{B}$ specific inhibitors or cysteine protease specific inhibitors (CA-074 methyl ester, E-64 and iodoacetic acid). However, serine protease specific inhibitors (PMSF and AEBSF) and trypsin specific inhibitor TPCK could only partially inhibit enzyme activity. EDTA had no inhibition on the activity, indicating that CsCBs belongs to the typical cathepsin B cysteine protease family.

\section{Immunohistochemistry of $C_{s} \mathrm{CB}$ in infected mice and liver cancer patients}

The liver tissues from mice model and patient samples were analyzed by immunohistochemistry using rat anti-CsCB4 antibody. Positive staining was indicated with brown. Compared to normal mice, strong staining was detected in the liver tissue of infected 


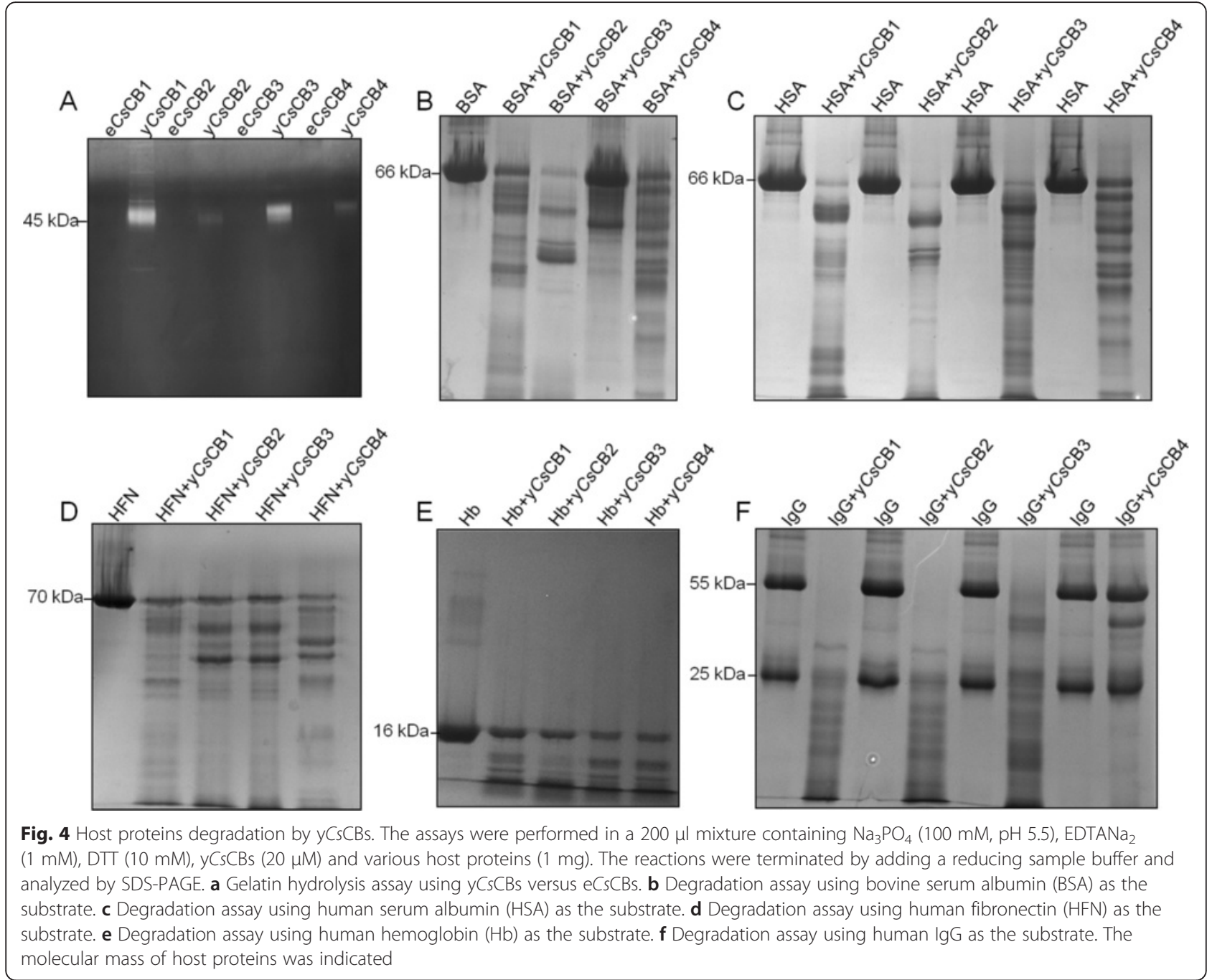

mice (Fig. 6a). The IOD of infected mice livers was significantly higher than the IOD of normal mice livers (Fig. 6b, $P<0.001$ ). Strong staining dispersed throughout the liver tissues from clonorchiasis patients, while little brown staining was evident in liver tissues from healthy people (Fig. 6c). The IOD of liver cancer specimens was higher than the IOD of normal liver specimens (Fig. 6d, $P<0.01$ ).

\section{Cell proliferation promoted by $\mathrm{CsCB}_{4}$}

The proliferation level of MHCC-97H and RBE cells treated with $\mathrm{yCs}$ CB4 4 was measured by CCK- 8 assays. As shown in Fig. 7a, both MHCC-97H and RBE cells treated with $\mathrm{yCs} C \mathrm{CB} 4$ showed significantly a higher proliferative level when compared to control cells $(P<0.05)$. To further confirm the effect of $\mathrm{yCs} C \mathrm{~B} 4$ on cell proliferation, we evaluated the distribution of the cell cycle by flow cytometry (Additional file 1: Figure S5). As shown in Fig. $7 \mathrm{~b}$, the G2/S percentage of MHCC-97H and $\mathrm{RBE}$ cells treated with $\mathrm{yCs} C \mathrm{CB} 4$ was statistically higher than those of cells treated with PBS control, respectively $(P<0.05)$.

\section{Cell migration and invasion triggered by $\mathrm{Cs} \mathrm{CB} 4$}

We wondered if $\mathrm{yCs} C B 4$ could play any role in cancer cell migration. To determine this, we carried out wound-healing assays. For both MHCC-97H (Fig. 7c) and RBE cells (Fig. 7e), at the concentration of $1 \mu \mathrm{g} / \mathrm{ml}$, $\mathrm{yCs} C B 4$ could induce significant cell migration, which is 3 -fold (Fig. 7d, $P<0.001$ ) and 2-fold (Fig. 7f, $P<0.05$ ) when compared to the PBS control, respectively. Similarly, in transwell assays, yCsCB4 $(1 \mu \mathrm{g} / \mathrm{ml})$ promoted a higher cell migration level in MHCC-97H (Fig. 8a) and RBE cells (Fig. 8b). In addition, the cell invasion level could also be reflected in transwell assays, indicating that at the concentration of $1 \mu \mathrm{g} / \mathrm{ml}$ yCsCB4 could induce a 3-fold (Fig. 8a, 

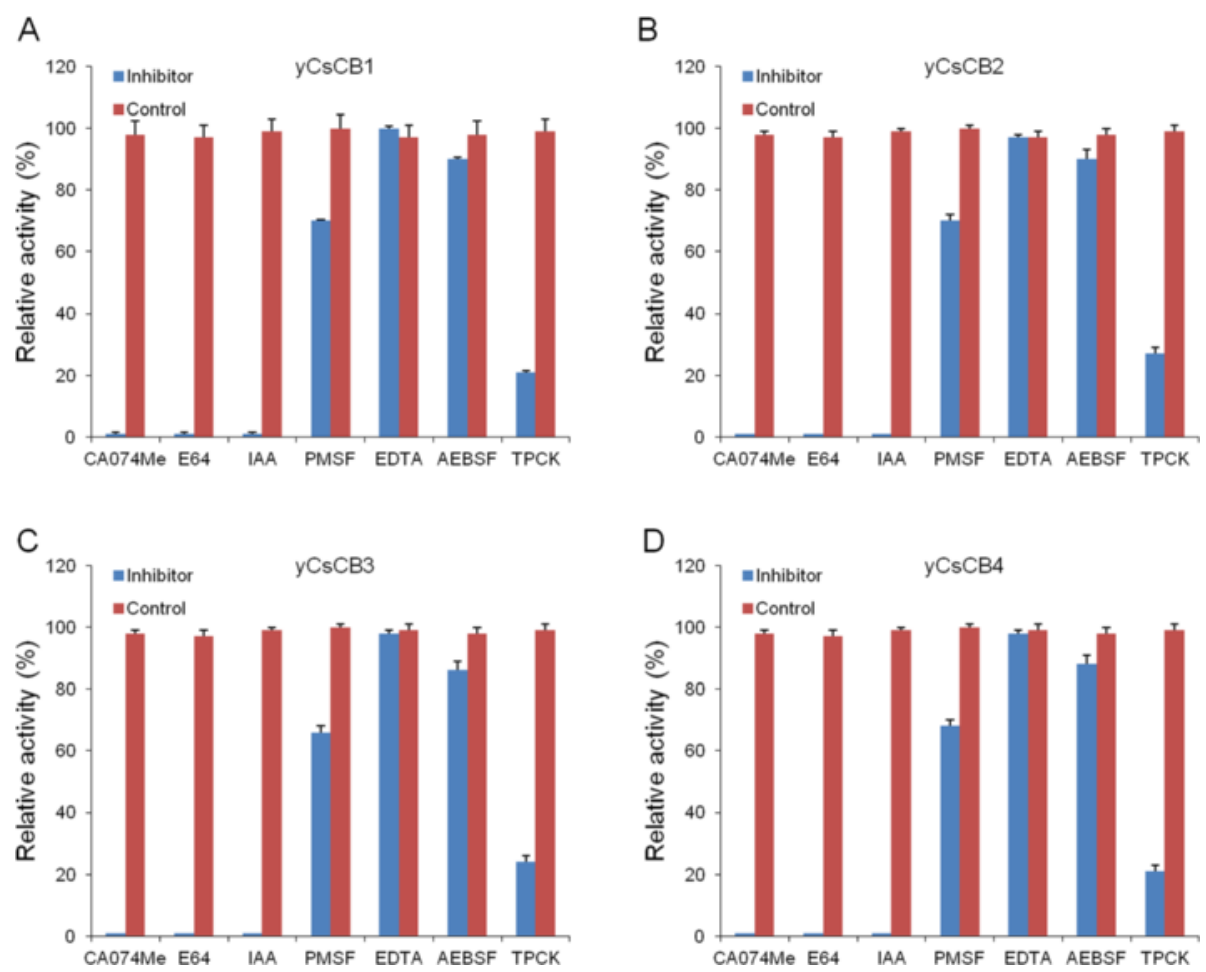

Fig. 5 Inhibition effect on enzyme activity of yCsCBs. a-d yCsCB1, yCsCB2, yCsCB3 and yCsCB4, respectively. yCsCBs (20 $\mu M$ ) were pre-incubated with or without protease inhibitors including E-64 $(20 \mu \mathrm{M})$, iodoacetic acid $(10 \mu \mathrm{M})$, PMSF $(2 \mathrm{mM})$, EDTA (2 mM), AEBSF $(200 \mu \mathrm{M})$, TPCK (200 $\mu \mathrm{M})$ and CA-074 methyl ester $(1 \mu \mathrm{M})$. Z-Phe-Arg-AMC $(20 \mu \mathrm{M})$ was added to the reactions after $30 \mathrm{~min}$ and incubated for another $1 \mathrm{~h}$. Fluorescent intensity was measured at $348 \mathrm{~nm}$ to calculate relative enzyme activity. Errors represent data from triplicate samples

$P<0.001$ ) and 5-fold (Fig. 8b, $P<0.001$ ) invasion level compared to the PBS control, respectively.

\section{Discussion}

Proteases are ubiquitous in nature and most organisms. In addition to their housekeeping functions, proteases are involved in the digestion of host proteins such as fibronectin, collagen and albumin, to facilitate migration and feeding in the host [19]. Cathepsins are of particular interest to parasitologists because there is considerable evidence that cathepsins are involved in parasitism. All of the trematodes have been shown to contain genes encoding cathepsin B-like proteins. For example, in Fasciola hepatica, cathepsin B was identified as an important factor associated with invasion of the mammalian host [20] and cathepsin B was suggested as a potential digestive factor in newly excysted juvenile parasites [21]. Cathepsin B was also identified as a stage and tissuespecific expression protease in Fasciola gigantica [22]. In Schistosoma mansoni, secreted cathepsin B was proposed to interact with host molecules and thus be a vital factor in parasitism [23]. In Angiostrongylus cantonensis, cathepsin B plays a potential role in the invasion of the central nervous system during parasite-host interactions
[24]. Thus, cathepsin B proteases clearly play an important role in the biology of trematode parasites. Cysteine proteases were abundant genes in $C$. sinensis genome and transcriptome. As the main components of $C$. sinensis excretory/secretory products, $\mathrm{Cs} C \mathrm{Bs}$ were proved to be potential vaccine candidates and diagnostic markers $[11,12]$. In this study, we constructed a eukaryotic expressing system by homologous recombination to express four $\mathrm{Cs} C \mathrm{Bs}$ in yeast. Active $\mathrm{yCs} \mathrm{CBs}$ were purified for biochemical and functional characterizations. The cellular effect of $\mathrm{CsCBs}$ on human cancer cells was observed using various cellular assays. Our results provide evidence to support the role of $\mathrm{Cs} C B s$ in the pathogenesis of clonorchiasis.

At this time, CsCBs were expressed in soluble form with enzyme activity because of the advantages of the methylotropic yeast, Pichia pastoris, and the shuttle vector pPICZ $\alpha \mathrm{B}[25,26]$. This shuttle vector facilitated our transformation operation from the $E$. coli system to the Pichia pastoris system. $\mathrm{yCs} C B \mathrm{~s}$ showed active enzyme activity with a wide range of $\mathrm{pHs}$, while peak enzymatic activity was assayed at $\mathrm{pH}$ 5.0-5.5, suggesting that $\mathrm{yCs} C B s$ were functional enzymes under acidic conditions. The hypothesis that $C s \mathrm{CBs}$ are acidic enzymes 


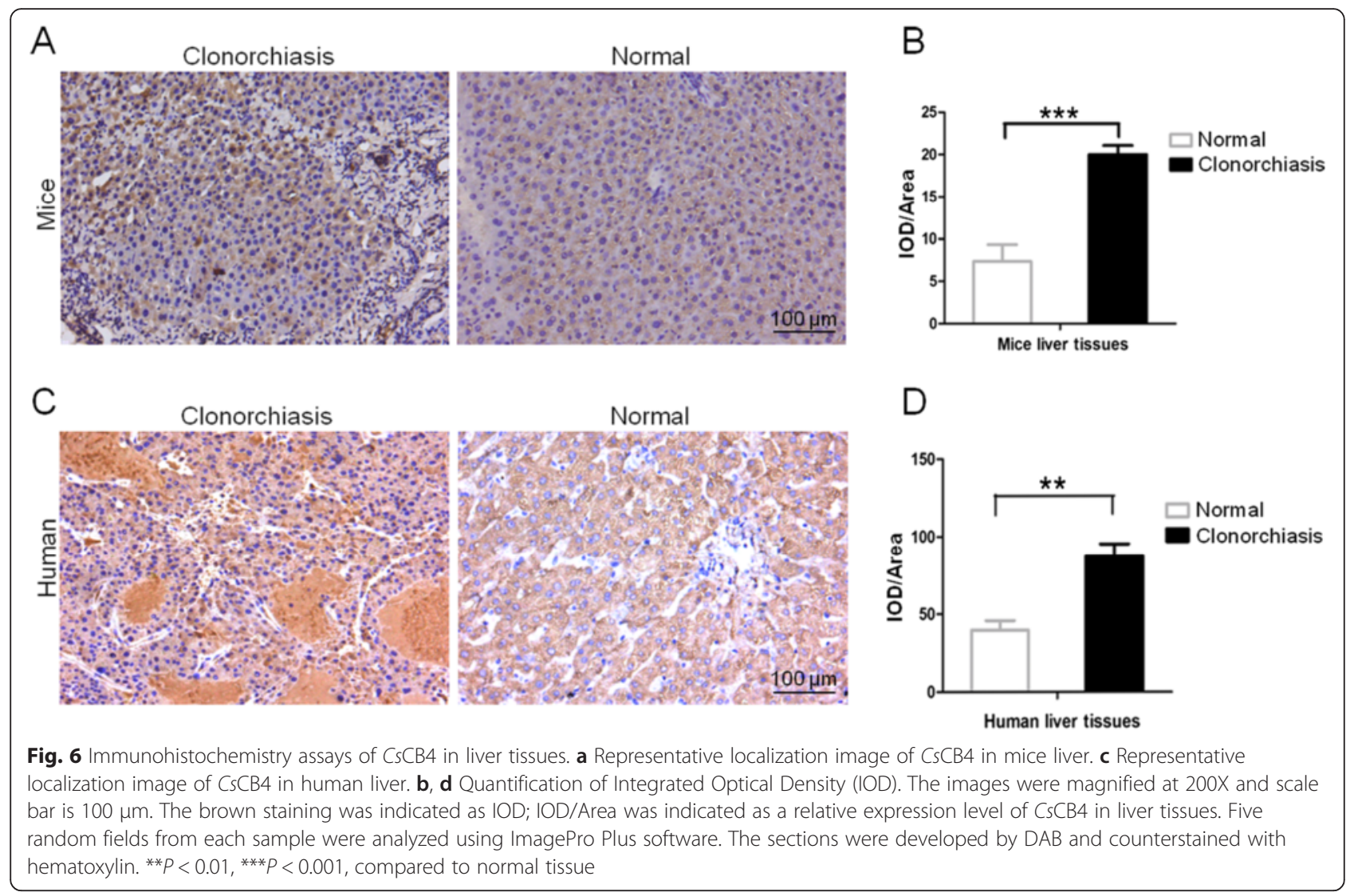

located in gut of flukes could be supported by previous reports $[23,27,28]$, considering the fact that the $\mathrm{pH}$ of the gut lumen of Fasciola hepatica has been suggested to be pH 5.5 [29]. Enzymatic activities of yCsCBs could be completely inhibited by cathepsin B specific inhibitors or cysteine protease specific inhibitors, while serine protease specific inhibitors and trypsin specific inhibitor showed only a weak inhibition effect. These results helped us confirm that our obtained $\mathrm{yCs} C B s$ belong to the typical cathepsin B cysteine protease family. In addition to typical enzymatic activities, $\mathrm{yCs} C B s$ could degrade all tested host proteins such as human serum albumin, human fibronectin, human hemoglobin and human IgG. Those host proteins have been used in other parasites to test the digestive effect of cathepsins [19]. For instance, $F h \mathrm{CB} 2$ could cleave serum albumin and IgG, indicating a role in the digestion of protein substrates for nutritional purposes [30]. Recombinant $\mathrm{FgCB} 3$ was recently shown to digest fibronectin, consistent with a role in digesting connective tissue and host invasion [31]. The digestive effect of yCsCBs supports our hypothesis that $\mathrm{Cs} \mathrm{CBs}$ serve as key virulence factors for $C$. sinensis, it is most likely that $\mathrm{Cs} C \mathrm{CBs}$ are involved in the pathogenesis of clonorchiasis. The biological role of $C s \mathrm{CB}$ could be implied by immunolocalization results, showing that $C s \mathrm{CBs}$ were localized in the excretory vesicle, oral sucker and intestinal tract of $C$. sinensis worms. Immunolocalization of $C s \mathrm{CB}$ is similar to $C$. sinensis cathepsin $\mathrm{F}$, which is also a secreted protein in the intestine of $C$. sinensis [32]. These two enzymes were expressed throughout developmental stages of the parasite. Given that $\mathrm{CsCBs}$ and $\mathrm{CsCFs}$ are from the same protease family, it is reasonable to assume they are synthesized in epithelial cells lining the parasite intestine followed by secretion into the intestinal lumen of the parasite, to play a role for nutrient uptake in the parasite [33-35].

As the key component of secreted products, many proteins have been connected with hepatobiliary diseases observed in individuals infected with liver flukes $[36,37]$. It was suggested that secreted products released by liver flukes could lead to pathologic changes in biliary epithelial cells $[38,39]$. Human cells exposed to ESPs from liver flukes (C. sinensis, Fasciola hepatica, and Opisthorchis viverrini) showed diverse pathophysiological responses including proliferation, apoptosis and inflammation [40-42]. In human diseases, experimental and clinical evidence have linked cathepsin B with tumor invasion and metastasis. Cathepsin B expression increases in many human 
A
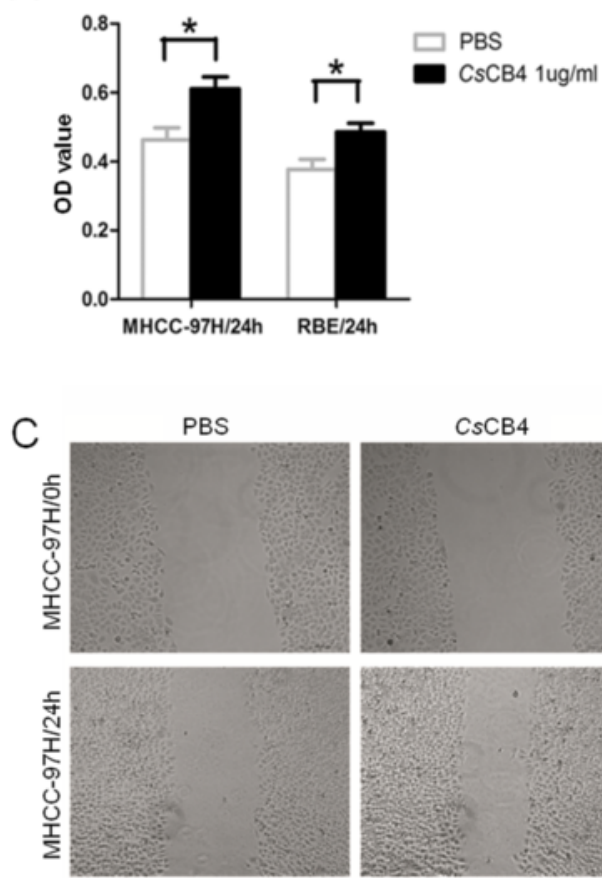

$E$

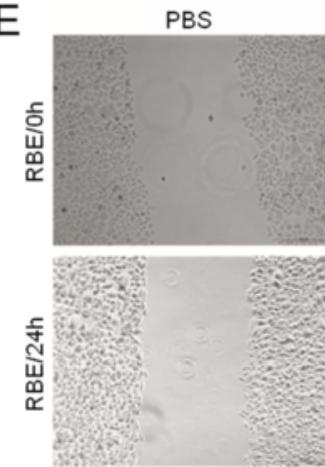

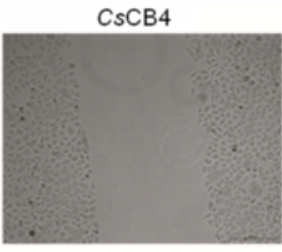
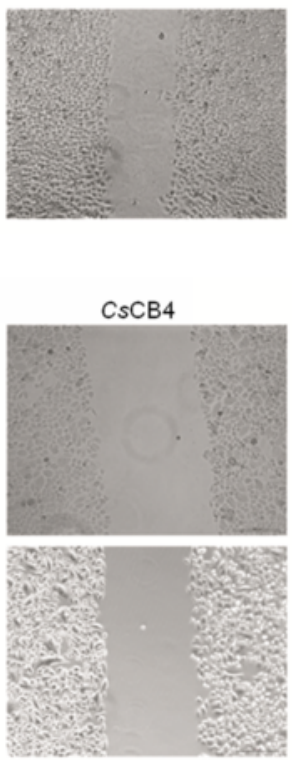

$\mathrm{B}$

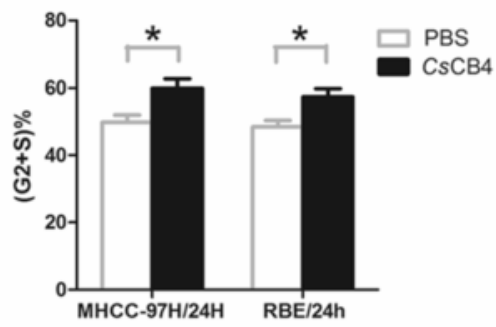

$\mathrm{D}$

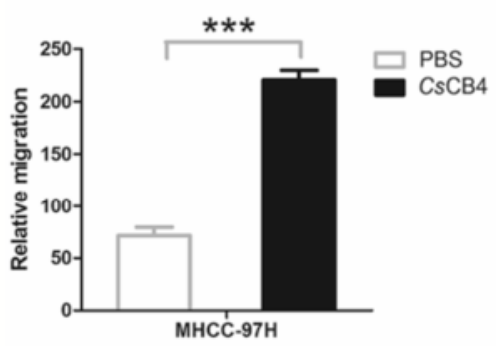

$\mathrm{F}$

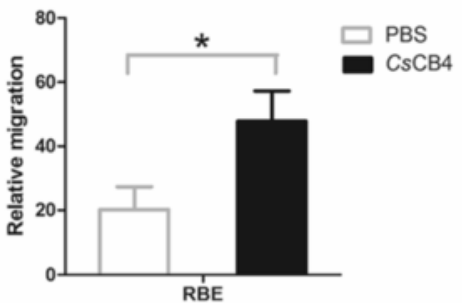

Fig. 7 The effect of yCsCB4 on human MHCC-97H and RBE cells. a Cell proliferation level measured by CCK-8 assay. b Cell cycle analysis by flow cytometry, the percentage of cells in the G2/S period was analyzed and quantified using FlowJo software. $\mathbf{c}$, d Cell migration of MHCC-97H cells shown by wound-healing assay. Cells were observed using light microscope under 10X objective. e, $\mathbf{f}$ Cell migration of RBE cells shown by wound-healing assays; cells were observed using a light microscope under 10X objective. Generally, MHCC-97H cells or RBE cells were incubated with $1 \mathrm{\mu g} / \mathrm{ml}$ of $\mathrm{yCsCB} 4$ or PBS for $24 \mathrm{~h}$ and assays were performed. Assays were performed in triplicate. Relative cell migration level was calculated by normalizing to cell migration level at $0 \mathrm{~h} .{ }^{*} P<0.05,{ }^{* *} P<0.001$, compared to PBS control

cancers at mRNA, protein and activity levels [43]. In this study, we found that $\mathrm{CsCB} 4$ was detected in liver tissues from infected mice or liver cancer patients induced by clonorchiasis. To gain a better understanding of $C s C B s$-associated human diseases, we measured the biological effects of $\mathrm{yCs} C B 4$ protein on human cancer cells. The results from different approaches demonstrated that $\mathrm{y} C s \mathrm{CB} 4$ could promote cell proliferation, cell migration and cell invasion of human hepatocellular carcinoma cells and human cholangiocarcinoma cells. Our observed results could be supported by our previous report that severin protein from CsESPs had an anti-apoptotic role in hepatocarcinoma PLC cells [44]. Given that four CsESPs have similar biochemical properties, it is conceivable that $\mathrm{Cs} C B s$ are involved in the pathogenesis of clonorchiasis during $C$. sinensis infection. However, further investigations are required in order to identify precise mechanisms to provide therapeutic strategies for clonorchiasis. With RNA interference applications in helminth $[45,46]$, it is feasible to 


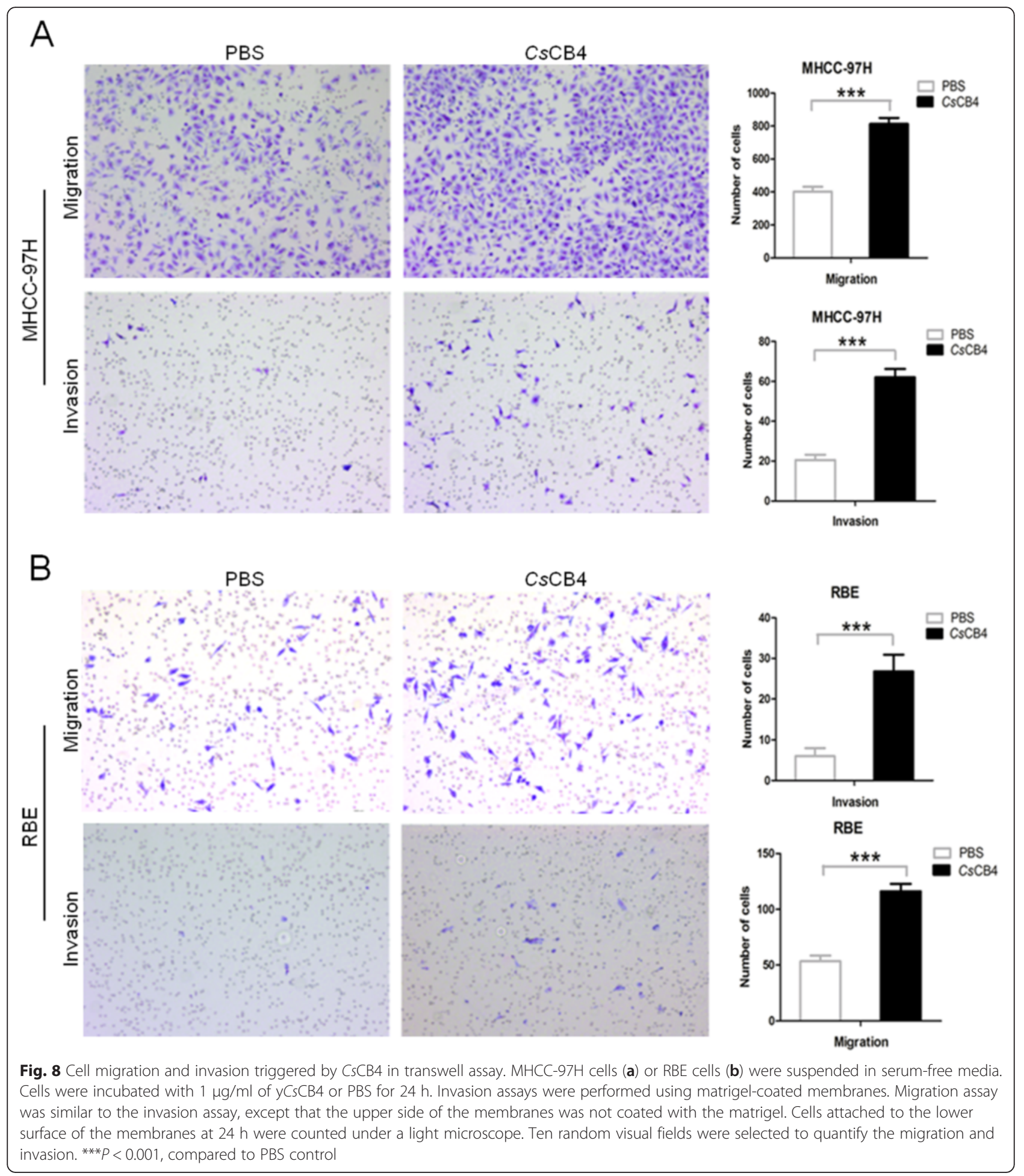

perform a $C s \mathrm{CBs}$-mediated intervention in C. sinensis associated diseases.

\section{Conclusion}

In summary, we expressed and purified four $\mathrm{Cs} C B \mathrm{Bs}$ in yeast and demonstrated that $C s C B s$ can degrade various human proteins. CsCBs could be detected at a high expression level in clonorchiasis-induced liver cancer tissues. In addition, our results indicate that $C s C B s$ could confer proliferative and invasive role in human cancer cells. The present study supports the involvement of $\mathrm{Cs} \mathrm{CBs}$ in the pathogenesis of clonorchiasis. 


\section{Additional file}

Additional file 1: Figure S1. Identification of recombinant plasmids by PCR amplification and restriction enzyme digestion. Figure S2. Identification of extracellular expression of yCsCBs by $12 \%$ SDS-PAGE. Figure S3. Identification of extracellular expression of $\mathrm{yCsCBs}$ by Western Blotting. Figure S4. Identification of purified protein of CSCBs by SDSPAGE. Figure S5. Representative cell cycle analysis by flow cytometry. (DOCX 5346 kb)

\section{Competing interests}

The authors declare that they have no competing interests.

\section{Authors' contributions}

WC, DN, XW, JX and XY conceived and designed the experiments; WC, DN, $X W, T C, X L$, JS and DW performed the experiments; WC, DN, XW and $Y H$ analyzed the data; $W C, D N, X W$ and $X Y$ wrote the manuscript. All authors read and approved the final manuscript.

\section{Acknowledgements}

This work was supported by Science and Technology Plan in Guangdong Province (No.: 2012ZX10004-220, 2013B010404010, 2014B020203001), National Key Basic Research and Development Project (973 project; No. 2010CB530000) and National Natural Science Foundation of China (No. $81171602)$ to XBY. This work was supported in part by National Natural Science Foundation of China (No. 81101270) to YH. We appreciate Prof Lifang Jiang (Department of Microbiology in Zhongshan School of Medicine at Sun Yat-sen University) for providing us shuttle vector pPICZaB and Pichia pastoris X33 cells.

\section{Author details}

'Department of Parasitology, Zhongshan School of Medicine, Sun Yat-sen University, Guangzhou, Guangdong 510080, People's Republic of China. ${ }^{2}$ Key Laboratory for Tropical Diseases Control of Ministry of Education, Sun Yat-sen University, Guangzhou, Guangdong 510080, People's Republic of China. ${ }^{3}$ Guangdong Provincial Institute of Public Health, Guangdong Provincial Center for Disease Control and Prevention, Guangzhou, Guangdong 511430, China. ${ }^{4}$ Department of Medical Laboratory and Research Center, Tangdu Hospital, Fourth Military Medical University, Xi'an, Shaanxi 710038, China.

Received: 20 November 2015 Accepted: 5 December 2015 Published online: 21 December 2015

\section{References}

1. Lun ZR, Gasser RB, Lai DH, Li AX, Zhu XQ, Yu XB, et al. Clonorchiasis: a key foodborne zoonosis in China. Lancet Infect Dis. 2005:5:31-41.

2. Lin J, Qu H, Chen G, He L, Xu Y, Xie Z, et al. Clonorchis sinensis acetoacetylCoA thiolase: identification and characterization of its potential role in surviving in the bile duct. Parasit Vectors. 2015;8:125

3. Sripa B, Kaewkes S, Intapan PM, Maleewong W, Brindley PJ. Food-borne trematodiases in Southeast Asia epidemiology, pathology, clinical manifestation and control. Adv Parasitol. 2010;72:305-50.

4. Hong ST, Fang Y. Clonorchis sinensis and clonorchiasis, an update. Parasitol Int. 2012;61:17-24

5. Huang SY, Zhao GH, Fu BQ, Xu MJ, Wang CR, Wu SM, et al. Genomics and molecular genetics of Clonorchis sinensis: current status and perspectives. Parasitol Int. 2012:61:71-6.

6. Wang X, Chen W, Huang Y, Sun J, Men J, Liu H, et al. The draft genome of the carcinogenic human liver fluke Clonorchis sinensis. Genome Biol. 2011; 12:R107

7. Yoo WG, Kim DW, Ju JW, Cho PY, Kim TI, Cho SH, et al. Developmental transcriptomic features of the carcinogenic liver fluke, Clonorchis sinensis. PLoS Negl Trop Dis. 2011;5:e1208

8. Nguyen TT, Arimatsu Y, Hong SJ, Brindley PJ, Blair D, Laha T, et al. Genomewide characterization of microsatellites and marker development in the carcinogenic liver fluke Clonorchis sinensis. Parasitol Res. 2015;114:2263-72.

9. Sithithaworn P, Yongvanit P, Duenngai K, Kiatsopit N, Pairojkul C. Roles of liver fluke infection as risk factor for cholangiocarcinoma. J Hepatobiliary Pancreat Sci. 2014;21:301-8.
10. Dvorak J, Delcroix M, Rossi A, Vopalensky V, Pospisek M, Sedinova M, et al Multiple cathepsin B isoforms in schistosomula of Trichobilharzia regenti: identification, characterisation and putative role in migration and nutrition. Int J Parasitol. 2005:35:895-910.

11. Chen W, Wang X, Li X, Lv X, Zhou C, Deng C, et al. Molecular characterization of cathepsin B from Clonorchis sinensis excretory/secretory products and assessment of its potential for serodiagnosis of clonorchiasis. Parasit Vectors. 2011;4:149.

12. Chen W, Wang X, Lv X, Tian Y, Xu Y, Mao Q, et al. Characterization of the secreted cathepsin $B$ cysteine proteases family of the carcinogenic liver fluke Clonorchis sinensis. Parasitol Res. 2014;113:3409-18.

13. Wang $X$, Liang $C$, Chen W, Fan $Y, H u X, X u$ J, et al. Experimental model in rats for study on transmission dynamics and evaluation of Clonorchis sinensis infection immunologically, morphologically, and pathologically. Parasitol Res. 2009:106:15-21.

14. Garg N, Bieler N, Kenzom T, Chhabra M, Ansorge-Schumacher M, Mishra S Cloning, sequence analysis, expression of Cyathus bulleri laccase in Pichia pastoris and characterization of recombinant laccase. BMC Biotechnol. 2012;12:75.

15. Barrett AJ, Kirschke H, Cathepsin B, Cathepsin H, Cathepsin L. Methods Enzymol. 1981;80(Pt C):535-61.

16. Zhang F, Liang $P$, Chen W, Wang X, Hu Y, Liang C, et al. Stage-specific expression, immunolocalization of Clonorchis sinensis lysophospholipase and its potential role in hepatic fibrosis. Parasitol Res. 2013:112:737-49.

17. Rodriguez LG, Wu X, Guan JL. Wound-healing assay. Methods Mol Biol. 2005;294:23-9.

18. Korpal M, Lee ES, Hu G, Kang Y. The miR-200 family inhibits epithelialmesenchymal transition and cancer cell migration by direct targeting of E-cadherin transcriptional repressors ZEB1 and ZEB2. J Biol Chem. 2008;283: 14910-4.

19. Smooker PM, Jayaraj R, Pike RN, Spithill TW. Cathepsin B proteases of flukes: the key to facilitating parasite control? Trends Parasitol. 2010;26:506-14.

20. Robinson MW, Menon R, Donnelly SM, Dalton JP, Ranganathan S. An integrated transcriptomics and proteomics analysis of the secretome of the helminth pathogen Fasciola hepatica: proteins associated with invasion and infection of the mammalian host. Mol Cell Proteomics. 2009;8:1891-907.

21. Beckham SA, Piedrafita D, Phillips Cl, Samarawickrema N, Law RH, Smooker PM, et al. A major cathepsin B protease from the liver fluke Fasciola hepatica has atypical active site features and a potential role in the digestive tract of newly excysted juvenile parasites. Int J Biochem Cell Biol. 2009:41:1601-12

22. Meemon K, Grams R, Vichasri-Grams S, Hofmann A, Korge G, Viyanant V, et al. Molecular cloning and analysis of stage and tissue-specific expression of cathepsin B encoding genes from Fasciola gigantica. Mol Biochem Parasitol. 2004;136:1-10.

23. Caffrey CR, Salter JP, Lucas KD, Khiem D, Hsieh I, Lim KC, et al. SmCB2, a novel tegumental cathepsin B from adult Schistosoma mansoni. Mol Biochem Parasitol. 2002:121:49-61.

24. Han YP, Li ZY, Li BC, Sun X, Zhu CC, Ling XT, et al. Molecular cloning and characterization of a cathepsin B from Angiostrongylus cantonensis. Parasitol Res. 2011;109:369-78.

25. Brankamp RG, Sreekrishna K, Smith PL, Blankenship DT, Cardin AD. Expression of a synthetic gene encoding the anticoagulant-antimetastatic protein ghilanten by the methylotropic yeast Pichia pastoris. Protein Expr Purif. 1995;6:813-20

26. Clare J J Romanos MA, Rayment FB, Rowedder JE, Smith MA, Payne MM et al. Production of mouse epidermal growth factor in yeast: high-level secretion using Pichia pastoris strains containing multiple gene copies. Gene. 1991;105:205-12.

27. Sajid M, McKerrow JH, Hansell E, Mathieu MA, Lucas KD, Hsieh I, et al. Functional expression and characterization of Schistosoma mansoni cathepsin B and its trans-activation by an endogenous asparaginyl endopeptidase. Mol Biochem Parasitol. 2003:131:65-75.

28. Lowther J, Robinson MW, Donnelly SM, Xu W, Stack CM, Matthews JM, et al. The importance of $\mathrm{pH}$ in regulating the function of the Fasciola hepatica cathepsin L1 cysteine protease. PLoS Negl Trop Dis. 2009;3:e369.

29. Halton DW. Nutritional adaptations to parasitism within the platyhelminthes. Int J Parasitol. 1997;27:693-704

30. Wilson LR, Good RT, Panaccio M, Wijffels GL, Sandeman RM, Spithill TW. Fasciola hepatica: characterization and cloning of the major cathepsin $B$ protease secreted by newly excysted juvenile liver fluke. Exp Parasitol. 1998; 88:85-94. 
31. Sethadavit M, Meemon K, Jardim A, Spithill TW, Sobhon P. Identification, expression and immunolocalization of cathepsin B3, a stage-specific antigen expressed by juvenile Fasciola gigantica. Acta Trop. 2009;112:164-73.

32. Kang JM, Bahk YY, Cho PY, Hong SJ, Kim TS, Sohn WM, et al. A family of cathepsin $\mathrm{F}$ cysteine proteases of Clonorchis sinensis is the major secreted proteins that are expressed in the intestine of the parasite. Mol Biochem Parasitol. 2010;170:7-16,

33. Kang TH, Yun DH, Lee EH, Chung YB, Bae YA, Chung JY, et al. A cathepsin F of adult Clonorchis sinensis and its phylogenetic conservation in trematodes. Parasitology. 2004;128:195-207.

34. Li S, Chung YB, Chung BS, Choi MH, Yu JR, Hong ST. The involvement of the cysteine proteases of Clonorchis sinensis metacercariae in excystment. Parasitol Res. 2004;93:36-40.

35. Na BK, Kang JM, Sohn WM. CsCF-6, a novel cathepsin F-like cysteine protease for nutrient uptake of Clonorchis sinensis. Int J Parasitol. 2008;38: 493-502.

36. Smout MJ, Laha T, Mulvenna J, Sripa B, Suttiprapa S, Jones A, et al. A granulin-like growth factor secreted by the carcinogenic liver fluke, Opisthorchis viverrini, promotes proliferation of host cells. PLoS Pathog. 2009:5:e1000611.

37. Pinlaor P, Kaewpitoon N, Laha T, Sripa B, Kaewkes S, Morales ME, et al. Cathepsin $\mathrm{F}$ cysteine protease of the human liver fluke, Opisthorchis viverrini. PLoS Negl Trop Dis. 2009;3:e398.

38. Cantacessi C, Mulvenna J, Young ND, Kasny M, Horak P, Aziz A, et al. A deep exploration of the transcriptome and "excretory/secretory" proteome of adult Fascioloides magna. Mol Cell Proteomics. 2012;11:1340-53.

39. Mulvenna J, Sripa B, Brindley PJ, Gorman J, Jones MK, Colgrave ML, et al. The secreted and surface proteomes of the adult stage of the carcinogenic human liver fluke Opisthorchis viverrini. Proteomics. 2010;10:1063-78.

40. Kim YJ, Choi MH, Hong ST, Bae YM. Proliferative effects of excretory/ secretory products from Clonorchis sinensis on the human epithelial cell line HEK293 via regulation of the transcription factor E2F1. Parasitol Res. 2008:102:411-7.

41. Techasen A, Loilome W, Namwat N, Duenngai K, Cha'on U, Thanan R, et al. Opisthorchis viverrini-antigen induces expression of MARCKS during inflammation-associated cholangiocarcinogenesis. Parasitol Int. 2012;61:140-4.

42. Ninlawan K, O'Hara SP, Splinter PL, Yongvanit P, Kaewkes S, Surapaitoon A, et al. Opisthorchis viverrini excretory/secretory products induce toll-like receptor 4 upregulation and production of interleukin 6 and 8 in cholangiocyte. Parasitol Int. 2010;59:616-21.

43. Reiser J, Adair B, Reinheckel T. Specialized roles for cysteine cathepsins in health and disease. J Clin Invest. 2010;120:3421-31.

44. Chen X, Li S, He L, Wang X, Liang P, Chen W, et al. Molecular characterization of severin from Clonorchis sinensis excretory/secretory products and its potential anti-apoptotic role in hepatocarcinoma PLC cells. PLoS Negl Trop Dis. 2013;7:e2606.

45. Sripa J, Pinlaor P, Brindley PJ, Sripa B, Kaewkes S, Robinson MW, et al. RNA interference targeting cathepsin $B$ of the carcinogenic liver fluke, Opisthorchis viverrini. Parasitol Int. 2011;60:283-8.

46. Wang X, Chen W, Tian Y, Huang Y, Li X, Yu X. RNAi-mediated silencing of enolase confirms its biological importance in Clonorchis sinensis. Parasitol Res. 2014;113:1451-8.

\section{Submit your next manuscript to BioMed Central and we will help you at every step:}

- We accept pre-submission inquiries

- Our selector tool helps you to find the most relevant journal

- We provide round the clock customer support

- Convenient online submission

- Thorough peer review

- Inclusion in PubMed and all major indexing services

- Maximum visibility for your research

Submit your manuscript at www.biomedcentral.com/submit

C Biomed Central 